\title{
Autoantibodies to the insulin receptor are infrequent findings in Type 1 (insulin-dependent) diabetes mellitus of recent onset
}

\author{
N. Rochet ${ }^{1}$, J.L. Sadoul ${ }^{2}$, B.Ferrua ${ }^{3}$, J. Kubar ${ }^{1}$, J.F.Tanti ${ }^{1}$, P. Bougnères ${ }^{4}$, B. Vialettes ${ }^{5}$, E. Van Obberghen ${ }^{1}$, \\ Y. Le Marchand-Brustel ${ }^{1}$ and P. Freychet ${ }^{2}$ \\ 1 INSERM U 145, Faculté de Médecine, \\ ${ }^{2}$ Service de Médecine Interne, Endocrinologie et Maladies Métaboliques, Hôpital Pasteur, \\ ${ }^{3}$ INSERM U210, Faculté de Médecine, Nice, \\ ${ }^{4}$ Service de Pédiatrie, Hôpital Saint Vincent de Paul, Paris and \\ ${ }^{5}$ Service de Médecine Interne et Nutrition, Hôpital de la Timone, Marseille, France
}

\begin{abstract}
Summary. To determine whether autoantibodies to the insulin receptor may represent markers of Type 1 (insulin-dependent) diabetes, the prevalence of such antibodies was investigated in sera of 60 newly diagnosed untreated Type 1 diabetic patients. A sensitive assay, based on enzyme linked immunosorbent assay has been set up which detects antibodies to the insulin receptor irrespective of their potentially inhibiting effect on insulin binding. Moreover, this method allows easy determination of the immunoglobulin class in-
\end{abstract}

volved in the anti-receptor activity. Among the 60 sera examined, only one was found to contain anti-insulin receptor autoantibodies (IgG class). In view of our data, we conclude that autoantibodies to the insulin receptor are infrequent findings in Type 1 diabetes of recent onset.

Key words: Autoantibodies, insulin receptor antibody, Type 1 (insulin-dependent) diabetes, diabetes autoimmunity, ELISA
Several findings have pointed to autoimmune mechanisms in the pathogenesis of Type 1 (insulin-dependent) diabetes mellitus [1-3]. Thus, the clinical onset of Type 1 diabetes is associated with a high prevalence of autoantibodies [4]. The search for potential markers of ongoing islet cell destruction deserves increasing attention since immunosuppressive therapeutic regimens could be considered when there are still a substantial amount of beta cells to be saved. Among those antibodies, the most representative and specific are islet cell antibodies (ICA) and anti-insulin antibodies (AIA) [5,6]. Autoantibodies to the insulin receptor were occasionally found to be part of such autoimmune constellations [7-9]. In such an autoimmune phenomenon, it is likely that the titre of antibodies would be low. This is a different situation from that observed in the rare syndromes of extreme insulin resistance (type B) where high titres of anti-insulin receptor antibodies have been found $[10,11]$. More recently, such autoantibodies were also reported in autoimmune hypoglycaemia [1218]. In these disease states, autoantibodies to the insulin receptor were readily detected by their capacity to inhibit the binding of insulin to its receptor [19-22]. But this technique could not detect antibodies not interfering with insulin binding as those recently described in man [23].

To examine the prevalence of antibodies to the insulin receptor in Type 1 diabetes, we have investigated 60 newly diagnosed diabetic patients at the clinical onset of the disease before any specific treatment. We have de- veloped a test, based on the ELISA technique which appears more sensitive than previously used methods (inhibition of insulin binding to its receptor; insulin-like activity of antibodies; immunoprecipitation of labelled receptors). This assay allows for the detection of various types of antibodies irrespective of their ability to interfere with insulin binding to its receptor.

\section{Subjects and methods}

\section{Materials}

$\mathrm{Na}^{125} \mathrm{I}$ was purchased from C.E. A. (Saclay, France). Wheat germ agglutinin agarose was from Sigma (St. Louis, Mo., USA). All other reagents were of the best grade commercially available and were from Sigma or Serva (Heidelberg, FRG). Peroxidase labelled anti-human antibodies were from Dakopak (Glostrup, Denmark).

\section{Subjects}

Sixty newly diagnosed Type 1 diabetic subjects (aged 3-67 years) were included in this study. Samples of serum were obtained before any treatment, particularly before insulin administration. The diagnosis of Type 1 diabetes was based on clinical history (polyuria, polydipsia, massive weight loss) and biological features (fasting blood glucose $>11.1 \mathrm{mmol} / \mathrm{l}$, constant glycosuria and ketonuria). These patients were investigated in three different centres as shown in 
Table 1. Characteristics of Type 1 (insulin-dependent) diabetic patients

\begin{tabular}{lcccll}
\hline Centre & $n$ & \multirow{2}{*}{$\begin{array}{c}\text { sex ratio } \\
\text { male/female }\end{array}$} & $\begin{array}{l}\text { mean age } \\
\text { (years) (range) }\end{array}$ & \multicolumn{2}{c}{ (\% positive patients) } \\
\cline { 5 - 6 } & & & & ICA & AIA \\
\hline Paris & 18 & $8 / 10$ & $8.6(3-12)$ & 75 & 71.4 \\
Marseille & 12 & $7 / 5$ & $19.3(6-35)$ & 77 & 33.3 \\
Nice & 30 & $23 / 7$ & $27.7(9-67)$ & 61 & 6.6 \\
\hline
\end{tabular}

ICA: islet cell antibodies; AIA: anti-insulin antibodies

Table 1 which also displays some clinical and immunological features of the patients.

Negative control sera were obtained from children and adults (aged 1-45 years), either healthy volunteers or patients being investigated for problems unrelated to immunology or diabetes. Positive control sera were from two types of patients: (1) Sera from patients with insulin resistance (type $B$ ) due to autoantibodies to the insulin receptor: $\mathrm{B} 2, \mathrm{~B} 3, \mathrm{~B} 4, \mathrm{~B} 7$, and $\mathrm{B} 10$ were kindly provided by $\mathrm{Dr}$. P. Gorden (National Institutes of Health, Bethesda, Md., USA); (2) Serum PS, studied in our laboratory, was from a child presenting with autoimmune hypoglycaemia in relation to autoantibodies to the insulin receptor [18]. The study was carried out in accordance with the principles of the Declaration of Helsinki.

\section{Preparation and purification of human insulin receptors}

Insulin receptors were prepared from rat embryo fibroblasts transfected with an expression plasmid encoding the human insulin receptor (expressing $10^{6}$ human receptors per cell) (HIR cells). Nontransfected cells were used as controls. Cells were cultured as previously described [24]. Receptors were solubilised in 1\% Triton X-100 and partially purified by chromatography on wheat germ agglutinin column [25]. Preparations obtained from HIR cells bound 500 (femtomol) of insulin per ml. Processing of the same number of cells, transfected or not, was performed in parallel on identical columns. Eluates from these columns were used as "Insulin Receptor Coating" and "Non-Specific Coating", respectively; they could be stored, without degradation, at $-80^{\circ} \mathrm{C}$ for a one year period.

Insulin receptors meant for iodination were prepared from transfected cells solubilised in $10 \mathrm{mmol} / \mathrm{l}$ (3-[(3-cholamidopropyl)dimethylammonio]-1-propanesulfonate) (CHAPS), purified by wheat germ agglutinin chromatography and immunoaffinity chromatography using a monoclonal antibody specific for human insulin receptor cross-linked to a CNBr-activated Sepharose matrix (Pharmacia, Uppsala, Sweden). The procedure was performed as previously described [26] except that $1 \%$ Triton X-100 was replaced by $10 \mathrm{mmol} / \mathrm{CHAPS}$.

\section{ELISA test}

The ELISA test was performed as follows: microtitre plates (Microtest III plates, Falcon, Becton Dickinson, Lincoln Park, NJ, USA) were coated overnight at $4^{\circ} \mathrm{C}$ with $100 \mu \mathrm{l}$ of the receptor preparations (diluted to have $3 \mathrm{fmol}$ insulin binding capacity) in $50 \mathrm{mmol} / 1$ carbonate coating buffer ( $\mathrm{pH}$ 9.6). Wells were then saturated for $2 \mathrm{~h}$ at room temperature with phosphate-buffered saline $(140 \mathrm{mmol} / \mathrm{l}$ $\mathrm{NaCl}, 3 \mathrm{mmol} / 1 \mathrm{KCl}, 6.5 \mathrm{mmol} / 1 \mathrm{Na}_{2} \mathrm{HPO}_{4}, 1.5 \mathrm{mmol} / \mathrm{l} \mathrm{KH}_{2} \mathrm{PO}_{4}$ ) containing bovine serum albumin ( $20 \mathrm{mg} / \mathrm{ml}$ ) (blocking buffer). All subsequent incubations were carried out at $15^{\circ} \mathrm{C}$ and plates were washed five times with saline buffer containing $0.1 \%$ Tween 20 after each of the following incubations. Serum samples $(100 \mu$ l of a $1 / 100$ dilution in blocking buffer) were added to the plates for $1 \mathrm{~h}$. Receptor-bound antibodies were then detected with horseradish peroxidase-conjugated rabbit anti-human IgG (dilution $10^{-4}$ ) or IgM (dilution $10^{-3}$ ), followed by incubation with the substrate solution for $30 \mathrm{~min}$ in the dark $(0.1 \mathrm{~mol} / \mathrm{l}$ phosphate, $44 \mathrm{mmol} / \mathrm{l}$ citrate buffer $\mathrm{pH} 5.5$ containing $0.02 \% \mathrm{H}_{2} \mathrm{O}_{2}$ and $16 \mathrm{mmol} / \mathrm{l} \mathrm{O}$-phenylenediamine dihydrochloride). Finally, the reaction was stopped with $100 \mu$ of $\mathrm{H}_{2} \mathrm{SO}_{4}$ $(2 \mathrm{~mol} / \mathrm{l})$ and absorbances were measured at $490 \mathrm{~nm}$ with a microplate reader. Within each microplate, each serum was tested twice with insulin receptor coating and once with non-specific coating. Background linked to the immunoglobulin content in the sera was taken into account given the use of non-specific coating. The specific signal was calculated as the difference between these two readings of absorbance. For negative control sera this difference was about zero. Background signal due to peroxidase labelled antibody was negligible $(0.037 \pm 0.001)$. Furthermore, in each plate test, serum B7 and serum B7 diluted (1/100) in normal serum were used as internal positive controls. The later control was made to reproduce artificially the conditions of a serum containing low titres of antibodies to the insulin receptor in a normal immunoglobulin environment.

Intraassay $(n=18)$ and interassay $(n=8)$ coefficients of variation of the ELISA test were $2.33 \%$ and $5.5 \%$, respectively.

\section{Immunoprecipitation of iodinated receptors}

Iodination of affinity purified insulin receptors was carried out with IODO-GEN iodination reaction (Pierce, Oud-Beijerland, The Netherlands). Unreacted iodine was separated from labelled receptors by Sephadex G- 25 chromatography. Five $\mu$ l of iodinated receptors was incubated overnight at $4^{\circ} \mathrm{C}$ with various dilutions of serum, in a final volume of $100 \mu 1$. Protein A Sepharose was then added for $1 \mathrm{~h}$ under constant shaking. Immune complexes were collected by centrifugation, washed three times with Hepes buffer $30 \mathrm{mmol} / \mathrm{l}$, $\mathrm{pH} 7.4, \mathrm{NaCl} 30 \mathrm{mmol} / \mathrm{l}$, CHAPS $10 \mathrm{mmol} / \mathrm{l}$, and radioactivity was measured.

\section{Islet cell cytoplasmic antibodies (ICA) and anti-insulin antibodies $(A I A)$}

Cytoplasmic type ICA were detected by immunofluorescence on a frozen section of human pancreas as recently recommended [27]. AIA were detected by the liquid phase radiobinding method described by Palmer [28].

\section{Insulin binding inhibition assay}

The human lymphoblastoid cell line (IM-9) was used for the insulin binding inhibition test. Cells were maintained in RPMI 1640 medium supplemented with $10 \%$ dialysed fetal calf serum. Inhibition of insulin binding on IM-9 cells was measured as previously described [22].

\section{Statistical analysis}

The upper limit of the normal range was defined as the mean $+3 \mathrm{SD}$ of the values obtained with negative control sera tested in the same experiment at the same dilution.

\section{Results}

Validation of ELISA to detect antibodies to insulin receptor

In order to validate our technique, ELISA results were compared with those obtained by immunoprecipitation of iodinated receptors and inhibition of insulin binding for positive and negative control sera. Figure 1 shows the de- 


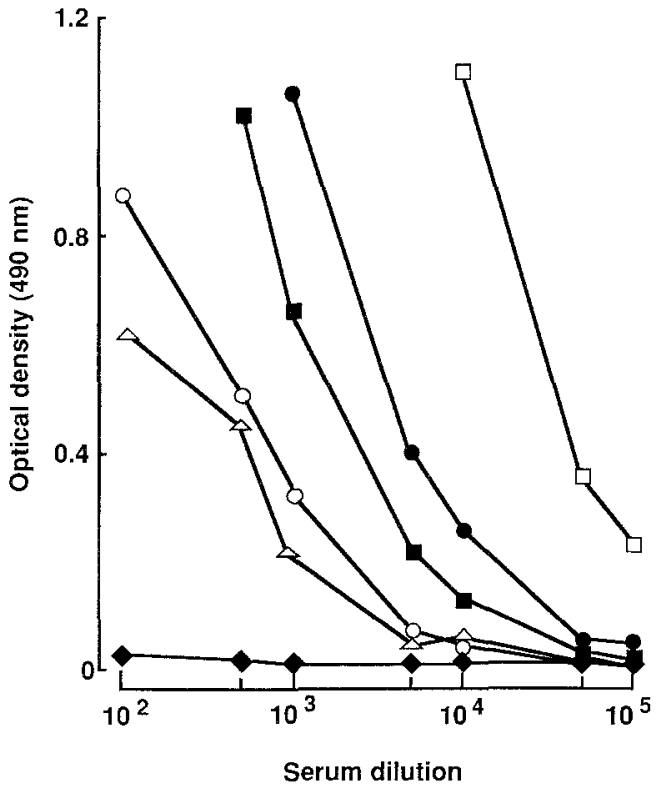

Fig. 1. Detection of autoantibodies to the insulin receptor by ELISA. Insulin receptors were prepared from rat embryo fibroblasts transfected with an expression plasmid encoding the human insulin receptor or from non-transfected cells. They were coated on microplates and ELISA was carried out with increasing dilutions of five sera from patients with type B insulin resistance: B2 ( $\square), B 3$ $(\triangle), \mathrm{B} 4(\boldsymbol{\square}), \mathrm{B} 7(\bullet), \mathrm{B} 10(\mathrm{O})$, and compared to the mean values of four normal sera $(\bullet)$. Anti-receptor antibodies were revealed with peroxidase-conjugated rabbit anti-human IgG. Specific absorbance was calculated by difference, for each dilution, between total signal and non-specific signal as described in Methods. Shown are the means of three experiments

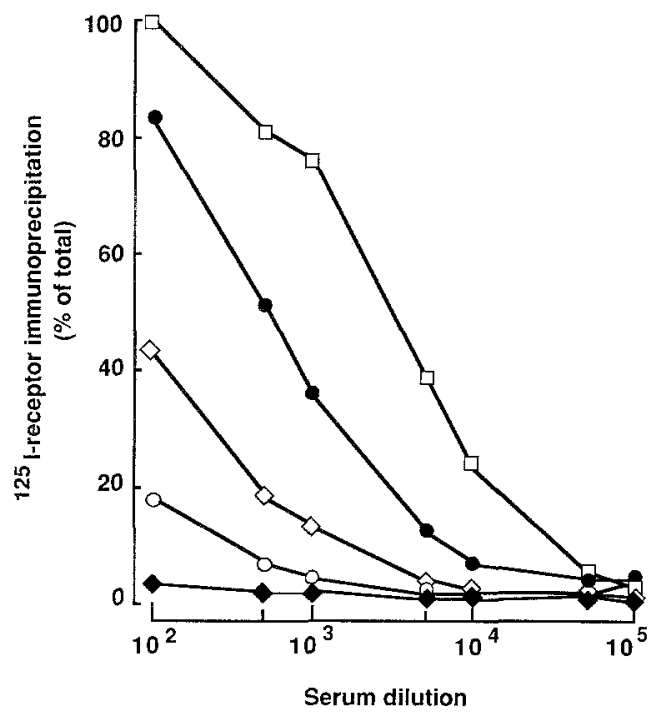

Fig. 2. Detection of autoantibodies to the insulin receptor by iodinated receptor immunoprecipitation. Iodinated receptors were incubated overnight at $4^{\circ} \mathrm{C}$, with various dilutions of sera from patients with type B insulin resistance: B2 ( $\square), \mathrm{B} 7(\bullet), \mathrm{B} 10(0)$, PS $(\diamond)$, or from negative control normal sera $(\bullet)$. Immune complexes were precipitated with protein $A$, and radioactivity measured as described. Results are expressed as a percentage of total immunoprecipitation, defined as the maximum immunoprecipitation achieved at $1 / 20$ (and below) dilution with the most potent serum tested (B2)

tection of antibodies to insulin receptor (IgG class) in positive control sera from five patients (B2, B3, B4, B7, $\mathrm{B} 10)$ with the type B syndrome of extreme insulin resis-
Table 2. Detection of insulin receptor autoantibodies in positive control serum (serum PS). Comparison of three different assays

\begin{tabular}{rlll}
\hline $\begin{array}{l}\text { Serum PS } \\
\text { dilutions }\end{array}$ & $\begin{array}{l}\text { \% inhibition of } \\
\text { insulin binding } \\
\text { to IM9 cells }\end{array}$ & $\begin{array}{l}\text { \% immunopre- } \\
\text { cipitation of iodi- } \\
\text { nated receptor }\end{array}$ & $\begin{array}{l}\text { ELISA } \\
\text { absorbance }\end{array}$ \\
\hline 100 & $33.6^{\mathrm{a}}$ & $43.75^{\mathrm{a}}$ & $1.664^{\mathrm{a}}$ \\
500 & 7.4 & $18.48^{\mathrm{a}}$ & nd \\
1000 & nd & $13.09^{\mathrm{a}}$ & $0.480^{\mathrm{a}}$ \\
10000 & nd & 2.05 & $0.067^{\mathrm{a}}$ \\
\hline
\end{tabular}

Various dilutions of serum PS were assayed using three different techniques. Inhibition of insulin binding to IM-9 cells as described previously [22]. Immunoprecipitation of iodinated insulin receptors was performed as follows: iodinated receptors were incubated overnight at $4^{\circ} \mathrm{C}$ with various dilutions of serum PS, immune complexes were precipitated with protein $\mathrm{A}$ and radioactivity measured. Results are expressed as a percentage of total immunoprecipitation, defined as the maximum immunoprecipitation achieved at $1 / 20$ dilution with the most potent serum tested (B2). ELISA was performed as follows. Insulin receptors from transfected or from non-transfected cells were coated on microplates and ELISA was carried out with increasing dilutions of serum from PS. Anti-receptor antibodies were revealed with peroxidase-conjugated rabbit anti-human IgG. Specific absorbance was calculated by difference, for each dilution, between total signal and non-specific signal as described in Methods. ${ }^{\text {a }}$ Positive results were defined as exceeding the mean $+3 \mathrm{SD}$ of values obtained with negative control sera at the same dilutions; nd $=$ not determined

tance $[10,11]$. Their sera were analysed at varying dilutions and compared to four negative control sera. Antibodies to the insulin receptor were detected in a concentration-dependent manner, whereas the specific signal with negative controls was almost zero. All five positive control sera were detected at dilutions as high as $1 / 10^{4}$ (Fig. 1), and three of them were still positive at $1 / 10^{5}$. The sensitivity of immunoprecipitation of iodinated receptors was analysed using various sera in a similar fashion (Fig. 2). As was observed in the ELISA, insulin receptor immunoprecipitation increased in a concentration-dependent manner for positive control sera and was negligible for the negative controls. The same rank order of potency was observed with the three positive control sera (B2, B7, B10) tested in the two assay systems (Fig. 1 and 2). However, the ELISA was distinctly more sensitive than the immunoprecipitation assay. Thus, sera B2, B7 and $\mathrm{B} 10$ were still positive in the ELISA at dilutions that were about one order of magnitude greater than those allowing detection by immunoprecipitation (Fig. 1 and 2).

The validity of ELISA was further assessed by comparing its results with those obtained by the insulin binding inhibition assay. Table 2 displays the signal obtained with a positive control serum (PS) [18] using the three screening assays. ELISA appeared to be 10 times more sensitive than the immunoprecipitation technique and at least 100 times more sensitive than inhibition of insulin binding (Table 2).

\section{Screening for antibodies to insulin receptor in Type 1 diabetes of recent onset}

Using this ELISA technique, we examined the sera of 60 Type 1 diabetic subjects at the onset of their disease, 


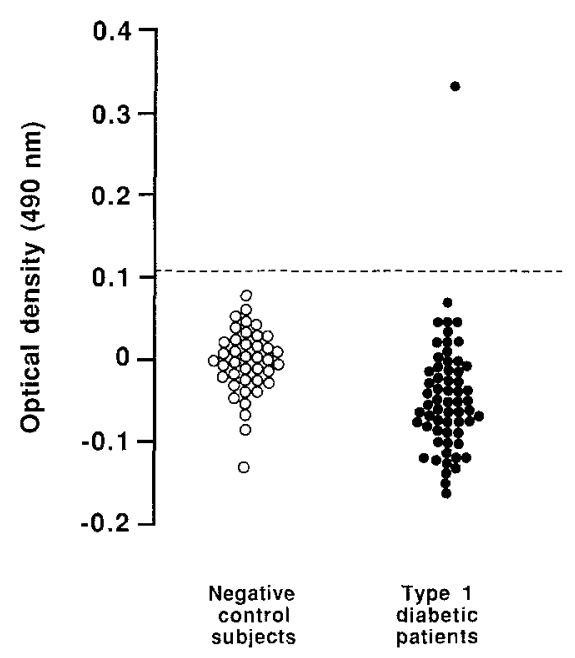

Fig. 3. Screening of $\operatorname{IgG}$ autoantibodies to the insulin receptor in diabetic patients. ELISA was carried out with sera (dilution 1/100) from Type 1 (insulin-dependent) diabetic patients $(n=60)$ and from negative control sera $(n=40)$ as described in Figure 1. Anti-insulin receptor antibodies were revealed with horseradish peroxidase-conjugated rabbit anti-human IgG. Specific absorbance is presented as in Figure 1. The dashed line indicates the value of the mean $+3 \mathrm{SD}$ of control sera, and defines the threshold of positivity

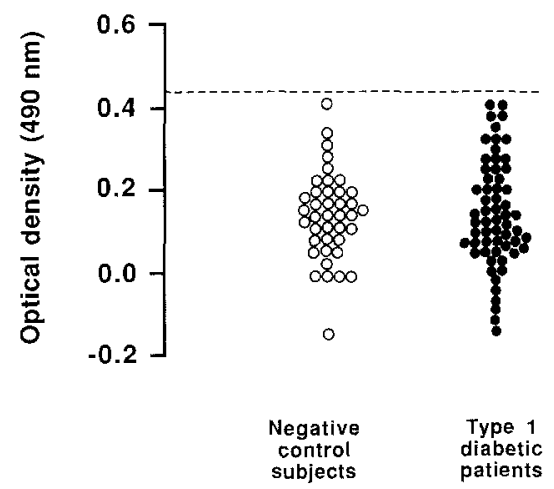

Fig. 4. Screening of $\operatorname{IgM}$ autoantibodies to the insulin receptor in Type 1 (insulin-dependent) diabetic patients. Sera were assayed at 1/50 dilution as described in Figures 1 and 3, and autoantibodies were revealed with a peroxidase-conjugated rabbit anti-human IgM. Specific absorbance is presented as in Figure 1

and compared them to 40 control sera. In order to screen both IgG and IgM type autoantibodies, the assays were performed with either peroxidase-conjugated antihuman IgG or anti-human IgM rabbit antibodies as the revealing antibody. As illustrated in Figure 3, only one serum (SR) was positive for autoantibodies to the insulin receptor of the IgG class. The positive serum gave absorbance values markedly higher than the upper limit of the normal range defined as the mean $+3 \mathrm{SD}$ of the values obtained with negative control sera. These results were obtained in three different assays performed on different days. No serum out of the 60 diabetic patients contained antibodies to insulin receptors of the IgM class (Fig. 4). Serum SR was also able to immunoprecipitate iodinated insulin receptor since it precipitated $52 \%$ and $37 \%$ of total iodinated receptors at $1 / 20$ and $1 / 100$ dilutions, respectively.

\section{Discussion}

Given the low titre of antibodies that could be expected for an autoimmune marker and the polyclonal nature of these antibodies, it is necessary, when testing a serum, to use either a set of complementary assays or a test that can detect all types of antibodies reacting with the insulin receptors. Whatever approach is taken, the sensitivity of the assay is critical. In order to meet these requirements, we have developed a test based on the ELISA technique. We have found that our ELISA has several advantages: (1) Its sensitivity is greater than that of other assays currently available; (2) It is capable of detecting antibodies to the insulin receptor regardless of their functional properties which may vary among these antibodies. Thus, it can detect antibodies to the insulin receptor not interfering with insulin binding domains as well as antibodies failing to recognize insulin receptors in an immunoprecipitation assay [29]; (3) With the use of the class specific peroxidase-labelled anti-human antibodies it is possible to determine, without any purification step, which class of immunoglobulin is involved in the anti-receptor activity; (4) Anti-insulin antibodies cannot interfere with this assay, as they can do in the insulin binding inhibition system and with immunoprecipitation of receptors cross-linked to iodinated insulin. Given the high prevalence of spontaneous AIA in newly diagnosed Type 1 diabetic subjects, especially in children [30], the test used for the detection must be devoid of such drawbacks; (5) The ELISA methodology, with a storable source of human antigen, and no need for radioactive reagents, makes this test readily available.

Using this test we have searched for antibodies to the insulin receptor in the sera of 60 newly diagnosed Type 1 diabetic patients. Only one serum (SR) was positive for antibodies of the IgG class, and none of them for antibodies of the IgM class. The clinical history of this patient is unusual. Briefly, SR is a man, aged 24 , whose glycaemic control was fairly well maintained for at least 20 months by an oral hypoglycaemic agent (glibenclamide, $10 \mathrm{mg} /$ day), despite a poor Beta-cell residual function. Indeed, the C-peptide level was very low $(190 \mathrm{pmol} / \mathrm{l})$ when fasting and did not increase significantly $(287 \mathrm{pmol} / 1$, $p>0.05$ ) after glucagon (1 mg i.v.).

Our results are not in agreement with three previously published studies [7-9]. The study by Maron et al. [7] was performed in 22 children before treatment with exogenous insulin. Antibodies were screened for their ability to inhibit insulin binding to rat adipocyte insulin receptors and by their capacity to stimulate lipogenesis. They were present in $45 \%$ of these children and were all of the $\operatorname{IgM}$ class. In addition to different methodological approaches, we cannot exclude the remote possibility that antibodies of the IgM class had undergone some degradation in our sera during prolonged storage, a classic phenomenon for IgM. However, it is also possible that Maron et al. detected antibodies against some rat species specific antigenic determinant. Ludwig et al. [8], reported three positive sera out of 29 newly diagnosed Type 1 diabetic patients, by measuring the inhibition of insulin binding to IM-9 cells. However, none of them would have been positive if they had used, as for their AIA assay, $3 \mathrm{SD}$ instead of $2 \mathrm{SD}$ 
above the mean values of control sera. Finally, it is difficult to interpret the study by Boden et al. [9], since three out of the five positive patients (among 51 diabetic patients) presented with other manifestations of autoimmune disease, and since most of their diabetic patients had been treated with insulin for many years.

Circulating ICA are an important indicator of Type 1 diabetes. The prevalence of ICA positivity varies from 55 to $80 \%$ in newly diagnosed diabetes mellitus. Although the pathogenic role of ICA is unclear, it has emerged as a predictive immunomarker of beta-cell destruction [5]. Besides ICA, it has become increasingly clear that Type 1 diabetes is, at least, associated with a B-lymphocyte polyclonal activation that results in the production of autoantibodies that are directed against a wide variety of antigens [4]. This is characteristic of polyendocrinopathies and the latter antibodies may be considered as non-specific and innocent bystanders of the autoimmune process [31]. Antibodies to the insulin receptor could have been representative of such a phenomenon. However, our data suggest that such antibodies are rather unusual in recently diagnosed Type 1 diabetes. Alternatively, antibodies to insulin receptor could arise as anti-idiotypes from AIA [32-34]. Indeed, AIA are, after ICA, the most frequent antibodies found in this clinical situation since they have been found to be positive in 20 to $40 \%$ of patients $[3,6,28$, $35]$. The idiotype of AIA could serve as an antigen for production of anti-idiotypes. This mechanism is unlikely, at least in our study, since no autoantibodies to insulin receptor were found in our paediatric subgroup (Paris, Table 1) despite a high percentage of positivity for AIA. Nevertheless, our ELISA is a sensitive assay to search for antibodies in clinical situations that can be linked to antibodies to the insulin receptor in a variety of autoimmune situations [31].

Acknowledgments. During this work, N. Rochet was recipient of a fellowship from the Fondation pour la Recherche Médicale (Paris, France). We thank Dr. A. Ullrich (Max Planck Institute Munich, FRG) for the generous gift of the HIR cells [24]. We are greatly indebted to Drs. D. Dupont, M. L. Gasiglia and B.Saggio for providing us with sera, and to Drs. B. Rossi and B. Canivet for helpful discussions. We thank A.Grima, C.Minghelli for illustration work and J.Duch for secretarial assistance. This work was supported by grants from Institut National de la Santé et de la Recherche Médicale, University of Nice-Sophia Antipolis, Fondation pour la Recherche Médicale and Bayer Pharma, France.

\section{References}

1. Bottazzo GF, Pujol-Borrell R, Gale E (1986) Autoimmunity and diabetes: progress, consolidation and controversy. In: Alberti KGMM, Krall LP (eds) The diabetes annual 2. Elsevier, London pp 13-29

2. Srikanta S, Ricker AT, McCulloch DK, Soeldner JS, Eisenbarth GS, Palmer JP (1986) Autoimmunity to insulin, beta cell dysfunction, and development of insulin-dependent diabetes mellitus. Diabetes 35: 139-142

3. Eisenbarth GS (1986) Type 1 diabetes mellitus: a chronic autoimmune disease. N Engl J Med 314: 1360-1368

4. Drell DW, Notkins AL (1987) Multiple immunological abnormalities in patients with Type 1 (insulin-dependent) diabetes mellitus. Diabetologia 30: 132-143
5. Vardi P, Dibella EE, Pasquarello TJ, Srikanta S (1987) Islet cell autoantibodies: pathobiology and clinical applications. Diabetes Care 10: 645-656

6. Atkinson MA, MacLaren NK, Riley WJ, Winter WE, Fisk DD, Spillar RP (1986) Are insulin autoantibodies markers for insulindependent diabetes mellitus? Diabetes 35: 894-898

7. Maron R, Elias D, de Jongh BM, Bruining GJ, Van Rood JJ, Shechter Y, Cohen IR (1983) Autoantibodies to the insulin receptor in juvenile onset insulin-dependent diabetes. Nature 303: 817-818

8. Ludwig SM, Faiman C, Dean HJ (1987) Insulin and insulin-receptor autoantibodies in children with newly diagnosed IDDM before insulin therapy. Diabetes 36: 420-425

9. Boden G, Fujita-Yamaguchi Y, Shimoyama R, Shelmet JJ, Tappy L, Rezvani I, Owen OE (1988) Nonbinding inhibitory antiinsulin receptor antibodies. J Clin Invest 81: 1971-1978

10. Kahn CR, Flier JS, Bar RS, Archer JA, Gorden P, Martin MM, Roth J (1976) The syndromes of insulin resistance and acanthosis nigricans: insulin-receptor disorders in man. N Engl J Med 294: 739-745

11. Flier JS, Kahn CR, Jarrett DB, Roth J (1976) Characterization of antibodies to the insulin receptor. A cause of insulin-resistant diabetes in man. J Clin Invest 58: 1442-1449

12. Taylor SI, Grunberger G, Marcus-Samuels B, Underhill LH, Dons RF, Ryan J, Roddam RF, Rupe CE, Gorden P (1982) Hypoglycaemia associated with antibodies to the insulin receptor. $\mathrm{N}$ Engl J Med 307: 1422-1426

13. Elias D, Cohen IR, Shechter Y, Spirer Z, Golander A (1987) Antibodies to insulin receptor followed by anti-idiotype. Antibodies to insulin in child with hypoglycemia. Diabetes 36 : 348-354

14. De Pirro R. Borboni P, Lauro R, Festa A, Testa I, De Martinis C, Maddux BA, Goldfine ID (1985) Tissue-specific antibodies against the fibroblast insulin receptor in a patient with lupus nephritis and hypoglycemia. Diabetes 34: 1088-1091

15. Braund WJ, Williamson DH, Clark A, Naylor BA, Buley ID, Chapel HM, Turner RC (1987) Autoimmunity to insulin receptor and hypoglycaemia in patient with Hodgkin's disease. Lancet I: $237-240$

16. Walters EG, Denton RM, Tavaré JM, Walters G (1987) Hypoglycaemia due to an insulin-receptor antibody in Hodgkin's disease. Lancet I: $241-243$

17. Moller DE, Ratner RE, Borenstein DG, Taylor SI (1988) Autoantibodies to the insulin receptor as a cause of autoimmune hypoglycemia in systemic lupus erythematosus. Am J Med 84: 334-338

18. Rochet N, Blanche S, Carel JC, Fischer A, Deist FL, Griscelli C, Van Obberghen E, Le Marchand-Brustel Y (1989) Hypoglycaemia induced by antibodies to insulin receptor following a bone marrow transplantation in an immunodeficient child. Diabetologia 32: 167-172

19. Flier JS, Kahn CR, Jarrett DB, Roth J (1977) Autoantibodies to the insulin receptor. Effect on the insulin-receptor interaction in IM-9 lymphocytes. J Clin Invest 60: 784-794

20. Le Marchand-Brustel Y, Gorden P, Flier JS, Kahn CR, Freychet $P$ (1978) Anti-insulin receptor antibodies inhibit insulin binding and stimulate glucose metabolism in skeletal muscle. Diabetologia $14: 311-317$

21. Taylor SI, Samuels B, Roth J, Kasuga M, Hedo JA, Gorden P, Brasel DE, Pokora T, Engel RR (1982) Decreased insulin binding in cultured lymphocytes from two patients with extreme insulin resistance. J Clin Endocrinol Metab 54:919-930

22. Taylor SI, Underhill LH, Marcus-Samuels B (1982) Assay of antibodies directed against cell surface receptors. Methods Enzymol 109: 656-667

23. Bloise W, Wajchenberg BL, Moncada VY, Marcus-Samuels B, Taylor SI (1989) Atypical anti insulin receptor antibodies in a patient with type B insulin resistance and scleroderma. J Clin Endocrinol Metab 68: 227-231

24. McClain DA, Maegawa H, Lee J, Dull TJ, Ullrich A, Olefsky JM (1987) A mutant insulin receptor with defective tyrosine kinase 
displays no biological activity and does not undergo endocytosis. J Biol Chem 262: 14663-14671

25. Van Obberghen E, Kasuga M, Le Cam A, Hedo JA, Itin A, Harrison LC (1981) Biosynthetic labeling of insulin receptor: studies of subunits in cultured human IM-9 lymphocytes. Proc Natl Acad Sci USA 78: 1052-1056

26. Tanti JF, Grémeaux T, Rochet N, Van Obberghen E, Le Marchand-Brustel Y (1987) Effect of cyclic AMP-dependent protein kinase on insulin receptor tyrosine kinase activity. Biochem $J$ 245: $19-26$

27. Bottazzo GF, Gleichmann H (1986) Immunology and Diabetes Workshops: report of the first international workshop on the standardisation of cytoplasmic islet cell antibodies. Diabetologia 29: $125-126$

28. Palmer JP, Asplin CM, Clemons P, Lyen K, Tatpati O, Raghu PK, Paquette TL (1983) Insulin antibodies in insulin-dependent diabetics before insulin treatment. Science 222: 1337-1339

29. Baron V, Gautier N, Rochet N, Ballotti R, Rossi B, Saint-Pierre S, Van Obberghen E, Dolais-Kitabgi J (1989) Antibodies to insulin receptor tyrosine kinase stimulate its activity towards exogenous substrates without inducing receptor autophosphorylation. Biochem J 260: 749-756

30. Vardi P, Ziegler AG, Mathews IH, Dib S, Keller RJ, Ricker AT, Wolfsdorf JI, Herskowitz RD, Rabizadeh A, Eisenbarth GS, Soeldner JS (1988) Concentration of insulin autoantibodies at onset of Type 1 Diabetes. Inverse Log-linear correlation with age. Diabetes Care 11:737-739

31. Salvi M, Fukazawa H, Bernard N, Hiromatsu Y, How J, Wall JR (1988) Role of autoantibodies in the pathogenesis and associ- ation of endocrine autoimmune disorders. Endocrine Rev 4: $450-466$

32. Shechter Y, Maron R, Elias D, Cohen IR (1982) Autoantibodies to insulin receptor spontaneously develop as anti-idiotypes in mice immunized with insulin. Science 216: 542-545

33. Shechter Y, Elias D, Maron R, Cohen IR (1984) Mouse antibodies to the insulin receptor developing spontaneously as antiidiotypes. I. Characterization of the antibodies. J Biol Chem 259: 6411-6415

34. Elias D, Maron R, Cohen IR, Shechter Y (1984) Mouse antibodies to the insulin receptor developing spontaneously as antiidiotypes. II. Effects on glucose homeostasis and the insulin receptor. J Biol Chem 259: 6416-6419

35. Dean BM, Becker F, McNally JM, Tarn AC, Schwartz G, Gale EAM, Bottazzo GF (1986) Insulin autoantibodies in the prediabetic period: correlation with islet cell antibodies and development of diabetes. Diabetologia 29: 339-342

Received: 25 October 1989

and in revised form: 5 February 1990

Dr. N. Rochet

INSERM U145

Faculté de Médecine

Avenue de Valombrose

F-06034 Nice Cedex

France 